\title{
Couples' Work Schedules and Child-Care Use in the Netherlands
}

\author{
Melissa Verhoef ${ }^{1} \cdot$ Anne Roeters $^{1} \cdot$ Tanja van der Lippe $^{1}$
}

Published online: 23 October 2015

(c) Springer Science+Business Media New York 2015

\begin{abstract}
Various aspects of parental work schedules affect the opportunities and constraints that parents encounter when arranging care for their children. This study examined the extent to which the combination of couples' work schedules was associated with their use of different types of child care, focusing on parental, formal, and informal child care. We considered multiple dimensions of couples' work schedules, namely, the timing of work, schedule flexibility, and home-based telework. Data from a recent Dutch survey were used, including information about 1599 dual-earner couples with children aged 0-6 years. The results indicated that paid work during nonstandard hours increased the amount of parental child care that was provided by one parent while the other parent was working, whereas work during evenings, nights, and weekends decreased the likelihood of using both formal and informal child care. Results further revealed gender differences for nonstandard hours and schedule flexibility. We found stronger effects of mothers' work schedules, indicating that a gender-neutral approach to parental work is not justified. These results indicate that the timing of parental work is important to consider when examining not only parental child care but also formal and informal childcare use. We provide recommendations for future research, specifically regarding the possible consequences for parental well-being.
\end{abstract}

Keywords Child-care arrangements - Dual earners . Families and work · Paid work - Work hours

Melissa Verhoef

m.verhoef@uu.nl

1 Department of Sociology, Utrecht University, PO Box 80.140, 3508 TC Utrecht, The Netherlands

\section{Introduction}

Child-care arrangements are a key factor within working families' daily lives. In many families, parents outsource part of their child care to formal and informal caregivers. Child-care arrangements matter because they are central to parents' everyday life. On the one hand, they can facilitate the combination of paid work and family life, an issue with which parents nowadays often struggle (Duncan and Pettigrew 2012). On the other hand, the coordination of child care can be quite complex in itself (Sandstrom and Chaudry 2012). Child-care arrangements are also associated with differences in child well-being (e.g., Bradley and Vandell 2007). Prior research has demonstrated that the extent to which parents outsource, and to whom they outsource, depends on characteristics of the parents, such as their work schedules, as well as on the characteristics of the available care, such as the availability and the accessibility (Kim and Fram 2009; Kimmel and Powell 2006; Van Klaveren et al. 2013; for a review, see Liu 2013).

Although previous studies considered the demand and supply arguments to be separate explanations, these arguments can also be considered in conjunction. Namely, parents' child-care arrangements depend on what is possible within the constraints of their work schedules. Some parents' needs may not align with the availability and accessibility of child care. This risk is likely to be highest for parents who work outside of office hours: these parents need to arrange care for their children during evenings, nights, and weekends when most formal child care is unavailable. At the same time, these parents may be better able to coordinate their working hours with those of their partner and the availability of their children. These alternatives present scholars with an interesting puzzle concerning parents' work and their use of different types of 
child care. Prior research on parental work schedules tended to focus on the impact on parent-child time and neglected alternative forms of child care, with a few notable exceptions (Han 2004; Presser 2003). These alternative forms of care can be categorized into formal child care-provided by professionals (Zinsser 2001) - and informal child care-provided by relatives or friends (Duncan et al. 2004).

Comparable to many other Western countries, various types of formal child care are available in the Netherlands. Parents can choose from day-care for preschoolers, out-ofschool care for school-aged children, and care provided by childminders for children of all ages (Dutch Government 2014). Formal child care is partially subsidized by the government depending on the parents' income. In 2013, parents' share of child-care costs was, on average, $37 \%$ (Dutch Bureau of Statistics 2014). The price for $1 \mathrm{~h}$ of care varied from $€ 5.44$ to $€ 6.57$, depending on the type of care (Dutch Ministry of Social Affairs and Employment 2014). A large proportion of Dutch parents use formal child care, but this is often for only a limited amount of hours (Plantenga and Remery 2009). Many Dutch parents also use informal child care to cover their working hours. Informal child care in the Netherlands covers a broad range of care, including care provided by au pairs or in playgroups, but the majority of informal care is provided by relatives and friends (Plantenga and Remery 2009). In the Netherlands, parental child care, defined as care that is provided by one parent of the child while the other parent is at work, is mainly provided by mothers. Recent figures show that Dutch mothers spend, on average, three times as many hours on child care compared with Dutch fathers (Merens et al. 2012). Although the Netherlands is known for its high part-time employment rates (EU Labour Force Survey 2013), the Netherlands also has a high percentage of dual-earner couples (Organisation for Economic Co-operation and Development (OECD) Family Database 2012), indicating a need for child care. Furthermore, up to $30 \%$ of Dutch parents work nonstandard schedules, which places the Netherlands among the European countries with the highest prevalence of parental nonstandard work (Presser et al. 2008). Thus, a significant proportion of Dutch parents have to arrange child care outside of standard service hours. This indicates that it is relevant to examine the link between parental work and child-care arrangements among Dutch parents.

Because the need for child care depends on the combination of parents' schedules, both partners should be taken into account. For example, the lack of child care outside office hours is particularly problematic if both parents work nonstandard hours. Although taking a couple-level approach is increasingly common in time use research that explains parental child care (e.g., Lesnard 2008; Roeters et al. 2009), it is surprisingly uncommon in the literature on nonparental child care. Although previous studies have provided valuable insights into different types of nonstandard work schedules, their focus has primarily been on mothers (Han 2004; Presser 2003). However, Gareis et al. (2003) demonstrate that parents are affected not only by the timing of their own work, but also by that of their partner. This points to the importance of taking a couple-level approach.

The timing of work, however, is only one dimension of work schedules. Scholars consider schedule flexibility and the opportunity to work from home as resources that enable parents to improve their combination of work and family demands (e.g., Fleetwood 2007). These are dimensions of work schedules that, similar to the timing of work, may affect couples' child-care opportunities and constraints because they facilitate the combination of paid work and child care (Osnowitz 2005; Tijdens and Dragstra 2007; Van Wel and Knijn 2006). The effects of these other dimensions of work schedules have been examined for parental child care (Carriero et al. 2009; Täht and Mills 2012), but they have not yet been examined for formal and informal child care, although similar mechanisms are applicable. So, when examining parents' child-care arrangements, multiple dimensions of work schedules need to be included, since these create different opportunities and constraints. As a result, parents evaluate parental, formal, and informal child care differently.

In the remaining part of the Introduction, we elaborate on how the work schedules of dual earners affect their use of parental, formal and informal child care. By focusing on the combination of work schedules, we exclude single parents, a group that has been found to encounter childcare related challenges more often than two-parent families (Moilanen et al. in press). Nevertheless, we are interested in the combination of work schedules and therefore we consider two parent households. Although we recognize that parents consider different types of child care simultaneously (Leslie et al. 2000), we discuss each type of child care separately to unravel the factors that are associated with arranging parental, formal, and informal child care. In our discussion of the previous literature, we consider multiple dimensions of couples' work schedules: the timing of work, schedule flexibility, and home-based telework. Each of these dimensions is likely to shape parents' opportunities and constraints when arranging different types of child care.

Starting with parental child care, the combination of both parents' work schedules, in terms of the timing of work, schedule flexibility and home-based telework, determines the availability and flexibility of parental care. The time that parents spend on certain tasks, such as work, is no longer available for other tasks, such as child care. 
Therefore, when discussing the time that couples have available to care for their children, the combination of parents' work schedules needs to be considered as well as the overlap between their work schedules.

Work during standard office hours, compared to other types of work schedules, is positively related to the level of overlap in parents' working hours (Lesnard 2008), which limits the time that parents have available to provide parental care. Multiple scholars argue that parental availability is higher when parents work nonstandard working hours, due to lower overlap in parents' working hours (e.g., Lesnard 2008; Presser 2003; Täht and Mills 2012). These studies, however, do not distinguish between couples with one or two nonstandard working schedules. This is a relevant distinction because the level of overlap in parents' work hours is likely to be larger when both work nonstandard hours. To illustrate, with two parents working nonstandard hours it is likely that both work during the evenings, whereas in couples in which only one parent works nonstandard hours the other parent is likely to be at home. Barnes et al. (2006) confirm this by showing that there is a substantial degree of overlap in the working hours of two nonstandard working parents, especially during the weekends. The combination of one standard and one nonstandard work schedule is examined more often (e.g., Hattery 2001; Wight et al. 2008), with results indicating that there is little overlap in parents' working hours if one parent works weekdays and the other parent works evenings, nights, or weekends. This situation gives parents the opportunity to 'split-shift' their parenting duties (Presser 2003), which allows parents to maximize child supervision (but see Han 2004, for a slightly different view on this subject). Thus, the level of overlap (and thus the need for nonparental child care) is likely to be highest when both parents work standard hours, lower when both work nonstandard hours and lowest when one parent works standard and the other parent works nonstandard hours.

Concerning the link between the other dimensions of couples' work schedules and parental child care, previous research has firstly shown that schedule flexibility gives employees the opportunity to determine their working times to a certain degree (Anderson et al. 2002). For example, employees are able, within a range, to choose the hours of their working day. Schedule flexibility has been found to reduce work interference with family (Byron 2005), which indicates that the ability to plan one's own working hours facilitates the combination of work and family. Parents could use this flexibility to make their working hours more compatible with their child-care needs, for example, by reducing the overlap in their work schedules. In this way, parents have more opportunities to care for their children themselves than do parents who do not have schedule flexibility. Second, home-based telework can be associated with parents' coordination of child care because this type of work makes it possible to structure the day around children's schedules (Osnowitz 2005). Home-based telework could therefore increase parents' opportunities to care for their children themselves compared with parents who do not work from home, because parents can work when their children are otherwise occupied (e.g., sleeping). Additionally, home-based telework eliminates parents' commuting time (Peters and Den Dulk 2003), which leaves more time available for other tasks, such as child care.

Turning to formal child care, it becomes apparent that the availability in the Netherlands is mainly restricted to standard service hours (8.00-18.00) on working days only (Education, Audiovisual and Culture Executive Agency (EACEA) 2009), although childminders offer somewhat more extensive possibilities. The flexibility of formal child care is also limited, because there is almost no variation possible in dropping-off and picking-up times, particularly at day-care institutions (Cloïn et al. 2010). When considering the availability and flexibility of formal child care, this type of care seems to offer especially good opportunities for dual-earner couples who have standard working hours. This is due to the large degree of overlap between parents' standard working hours and the open hours of formal child-care institutions. In addition, due to the nature of their work schedules, the demand for flexibility is low, which makes formal child care a good fit for dual-earner couples who include two standard working parents. For couples in which one parent works nonstandard hours, the same reasoning applies to a certain extent, because the standard working parent is able to drop off and pick up the children during standard service hours. Yet, because these parents cannot share the formal child-care responsibilities, arranging formal child care could become problematic. Availability and flexibility certainly form a constraint for couples in which both parents work nonstandard hours, because these couples need child care outside standard service hours and preferably flexible in nature (Kimmel and Powell 2006). Hence, formal child care will be a less logical option for these couples.

With regard to the link between the other dimensions of couples' work schedules and formal child care, parents with schedule flexibility are able to plan their work around the open hours of formal child-care institutions. Because the open hours of Dutch formal child-care institutions are quite strict (EACEA 2009), schedule flexibility gives parents the opportunity to match these open hours with their working hours, thereby increasing the likelihood that they will use formal child care. The same reasoning applies to home-based telework, because working at home makes it possible to structure the working day around the children (Osnowitz 2005). Therefore, parents who work at home are better able to work around the open hours of child-care 
institutions and have a higher likelihood of using formal child care than parents who do not work from home.

Regarding informal child care, existing literature offers three possible reasons why this type of care is most likely to be used by parents who work outside office hours. First, in contrast to formal child-care institutions, which often have limited availability outside of office hours, the availability of informal care is not restricted to particular opening hours. Presser (2003) argued that as a result of the wide availability of informal child care, parents who work evenings, nights or weekends often rely on informal child care. Second, parents might feel more comfortable to place their children in informal care overnight (Brown-Lyons et al. 2001). Third, parents perceive informal care as more flexible than formal child care (Bakker and Karsten 2013), which is likely to be another advantage of informal child care that is especially relevant for parents with irregular hours. Yet, the availability and flexibility of informal child care can only go so far, because informal caregivers may be otherwise engaged, for example in work responsibilities (Chaudry 2004). Nonetheless, this type of care offers good opportunities for parents with nonstandard working hours, particularly when both parents work during evenings, nights, or weekends. Due to their working hours, these couples namely need flexible child care outside of standard service hours (Kimmel and Powell 2006) and rely heavily on informal care. The same reasoning applies, to a certain extent, to couples in which one parent works nonstandard hours. But because one parent works during standard hours in these couples, flexibility may be less of an issue. These couples, therefore, rely less heavily on informal child care than do couples in which both parents work nonstandard hours. The likelihood of using informal child care for couples with two standard work schedules will be the lowest, because these couples can benefit the most from the opportunities offered by formal child-care services. Still, because previous research has shown that Dutch parents only use formal child care for a limited amount of hours (Plantenga and Remery 2009), these parents will still use informal child care to a certain degree.

Existing literature provides a less clear picture regarding the associations between the other dimensions of couples' work schedules and the use of informal child care. Informal child care is perceived as flexible (Bakker and Karsten 2013) and usually unpaid (Wheelock and Jones 2002), which makes it an affordable and accessible type of child care. Therefore, arguments that are similar to the case of formal child care are absent, which makes it hard to discuss the likelihood of using informal child care for parents that have schedule flexibility and/or work from home.

Previous research has provided more clear arguments regarding the importance of differentiating between mothers and fathers when examining work schedules of dual- earner couples. According to Bielby (1992), mothers are more motivated than fathers to use work-related resources for the benefit of the family. This difference reflects a distinction in mothers and fathers' sense of responsibility for child care. In addition, mothers have greater responsibility for managing family time, compared to fathers (Craig and Powell 2011). Several time use studies confirmed this idea by showing that, among dual-earner couples, mothers' work schedules are more strongly related to parent-child time, compared to fathers' work schedules (Lesnard 2008; Roeters et al. 2010). Therefore, it is likely that mothers' work schedules have a stronger association with child-care arrangements than fathers' work schedules do.

The current study aims to create more insight into the association between couples' work schedules and their child-care arrangements among Dutch parents. We build on earlier research by distinguishing between different types of child care and taking a couple-level perspective. We compare different schedule combinations in our hypotheses, focusing on the timing of work, schedule flexibility and home-based telework. We expect that: (1) the amount of provided parental child care will be highest if one parents works nonstandard hours, lower if both parents work nonstandard hours, and lowest if both parents work standard hours; (2) the amount of provided parental child care will be higher if one parent (a) has schedule flexibility or (b) works from home than if both parents have no schedule flexibility, and do not work from home; (3) the likelihood of using formal child care will be highest if both parents work standard hours, lower if one parent works nonstandard hours, and lowest if both parents work nonstandard hours; (4) the likelihood of using formal child care will be higher if one parent (a) has schedule flexibility or (b) works from home than if both parents have no schedule flexibility, and do not work from home; and (5) the likelihood of using informal child care will be highest if both parents work nonstandard hours, lower if one parents works nonstandard hours, and lowest if both parents work standard hours. For Hypotheses 2 and 4, we expect the associations to be stronger if both parents have schedule flexibility or work from home. We differentiate between mothers and fathers, because the associations between parental work and child care are expected to be more pronounced for mothers. This only refers to parental child care, because decisions on formal and informal child care are made on the family level.

\section{Method}

\section{Participants}

For this paper, we analyzed data from the 2013 'Krimp in Kinderopvang' (KiK) study on child-care use in the 
Netherlands (Netherlands Institute for Social Research \& Dutch Bureau of Statistics, 2013). This is a rich dataset containing recent information about how Dutch parents arrange the care of their children. The data are cross-sectional, which prevents us from making causal inferences. For example, couples with certain child-care preferences may select themselves into specific work schedules. Nonetheless, we believe that our study provides valuable insights into the child-care issues many working parents have to deal with.

The total sample consisted of 2178 parents with children aged six or younger. Because the focus of this paper is on dual earners, 116 parents were excluded for not having a partner. Another 384 parents were excluded because they reported that either they $(n=248)$ or their partner $(n=92)$ did not have a job. Lastly, because most of the variables that are included in the analyses have a few missing values (ranging from 0.06 to $2.93 \%$ ), another 123 parents were excluded due to listwise deletion. The final sample consists of 1599 dual-earner couples. In 1473 $(92.12 \%)$ of the cases, the mother responded to the questionnaire. A comparison of the characteristics of the sample with the general Dutch population with children showed that our sample is higher educated and has a higher household income (Dutch Bureau of Statistics 2012a, b). The majority of the mothers $(54.35 \%)$ and $46.03 \%$ of the fathers finished at least postsecondary education. The average yearly household income was €89,384 $(\mathrm{SD}=43,367)$ before taxes.

\section{Procedure}

Two groups of parents were approached; the parents were randomly selected based on the characteristics of their children by using information from the Dutch Municipal Personal Records Database and the Dutch Tax Administration (Portegijs et al. 2014). The first group consisted of 81,617 parents who had their first child in 2012, of whom 2500 parents were randomly selected to participate in the survey. The second group consisted of 83,335 parents whose first child started primary school in 2012, of whom another 2500 randomly selected parents were invited to participate. A paper-and-pencil questionnaire was attached to the letter of invitation along with a link to the digital questionnaire, which enabled parents to choose the most convenient way to respond to the survey. One parent per family responded to the survey, with the majority $(91.32 \%)$ being female. Parents were instructed to answer all of the child-related questions with information about either their child who was born in 2012 or their child who started primary school in 2012 (i.e., the target child). Each respondent also provided information about his or her partner, such as information on the partner's background, child-care provision, and work schedule. Data collection took place between September and November 2013. The response rate of the survey was $43.56 \%$, which is comparable to that of other family surveys in the Netherlands (e.g., Dykstra et al. 2005). In the Netherlands, response rates are often lower than in other countries (De Leeuw and De Heer 2001).

\section{Measures}

\section{Child-Care Use}

The amount of parental child care that couples provide was measured by asking whether the respondent or their partner was at home during workdays to care for their child while the other parent was at work. Respondents could either reply no or yes, after which they were asked for how many days a week. This information was used to calculate the amount of days that parents were at home to care for their child while their partner was at work, which represents the amount of provided parental child care.

Formal and informal child-care use was assessed by asking whether the target child was regularly (at least half a day on a weekly basis) cared for by someone other than the respondent or their partner while they were at work. If so, the next question asked about who cared for the child, for which the respondents could choose day-care, out-ofschool care, childminder, and relatives, friends, or acquaintances. From these questions, two binary variables were computed: formal child care for those whose child was cared for in day-care, out-of-school care, or by a childminder $(0=n o, 1=y e s)$, and informal child care for those whose child was cared for by relatives, friends, or acquaintances $(0=n o, 1=y e s)$. Please note that these binary variables are not mutually exclusive; it is possible that couples reported using both formal and informal child care.

\section{Timing of Work}

Respondents were asked about the timing of their work in the following way: 'Do your official working hours always take place on weekdays between 7 a.m. and 6 p.m.?' Respondents could reply yes, or they could reply no, which would mean that they (also) worked outside office hours or during the weekend. Respondents were also asked about the timing of their partner's work, using the same question. The combination of couples' responses was divided into three categories, for which dummy variables were created $(0=n o, 1=y e s)$ : both parents work a standard schedule; one parent works a standard schedule, and the other parent works a nonstandard schedule; both parents work a nonstandard schedule. 


\section{Schedule Flexibility}

Schedule flexibility was measured by asking whether respondents were able to adjust their working hours to their child-care needs by, for example, starting later or finishing earlier. Respondents also provided information on the schedule flexibility of their partner. The answer categories varied from 1 (Yes, I do this often, on average once a week) to $4(\mathrm{No})$. Three dummy variables were created that indicated whether none, one, or both parents within a dualearner couple actively used schedule flexibility $(0=n o$, $1=y e s$ ). Actively using schedule flexibility implied that parents adjusted their working hours at least once a month.

\section{Home-Based Telework}

To measure home-based telework, respondents were asked whether they or their partner were able to work from home. Answer categories varied from 1 (Yes, I do this often, on average once a week) to 4 (No). Again, three dummy variables were created that indicated whether none, one, or both parents actively worked from home $(0=n o$, $1=y e s)$. Actively working from home implied that parents did this at least once a month.

\section{Control Variables}

We controlled for the couples' mean educational level $(0=$ secondary education or lower, $1=$ postsecondary education or higher), the family's yearly household income, the age of the target child and the number of children in the household. Parents' likelihood of using formal child care is expected to be higher if parents are more highly educated (Early and Burchinal 2001) or have a higher income (Ehrle et al. 2001). Furthermore, the likelihood of using any form of child care is expected to be lower if children are older (Casper and Smith 2004), whereas parents are expected to provide more parental child care if they have more children (OECD Family Database 2009). We also controlled for working overtime, to avoid accidentally capturing overwork instead of nonstandard work $(0=n o, 1=y e s$, by at least one of the parents), and for mothers' and fathers' actual weekly working hours.

\section{Data Analyses}

Our analytical strategy consisted of three parts. First, couples' amount of provided parental child care was analyzed using an ordinary least squares (OLS) regression. In this analysis, we included the control variables, the dummy variables that represented couples' timing of work combinations, and the dummy variables for schedule flexibility and home-based telework. Second, couples' likelihood of using formal and informal child care was examined using multivariate logistic regression. This method of analysis entails more precision, compared to two separate logistic regression analyses, because it uses all information about both outcome variables and it takes into account the correlation between dependent variables (Lu and Yang 2012). For this analysis, the same variables were included as in the examination of parental child care. Third, additional analyses were performed to examine gender differences in parental work schedules for parental, formal, and informal child care. Analyses were performed using Stata 12.

\section{Results}

Descriptives are presented in Table 1. Dual-earner couples provide parental child care for just over 2.5 days a week, on average. Regarding nonparental child care, Table 1 shows that the majority of the parents use formal and informal child care. Almost half of the respondents are part of a dual-earner couple in which both parents work standard hours. Couples in which one of the parents works nonstandard hours are slightly less common; couples with two nonstandard working parents are quite rare.

Table 1 further indicates that in just over half of the couples, either one or both of the parents switch their working hours at least once a month. Parents work from home less frequently; less than half of the parents work at home at least once a month. Almost half of the couples reported working overtime on a weekly basis. The amount of weekly working hours is indicative of the Dutch oneand-a-half earner model (Mills et al. 2008), with mothers working part-time $(\mathrm{M}=27.28, \mathrm{SD}=8.04)$ and fathers working full-time $(\mathrm{M}=38.16, \mathrm{SD}=4.79)$.

The results of the OLS regression analysis for the amount of provided parental child care are presented in the second column of Table 2 . The results indicate that couples in which one parent works during nonstandard hours provide more parental child care than couples in which two parents work a standard work schedule $(B=0.46$, $p<.001)$. For couples in which both parents work nonstandard hours, the effect was even larger $(B=0.94$, $p<.001)$. Alternating the reference category showed that couples with two nonstandard working parents provide significantly more parental child care than couples in which one parent works nonstandard hours $(B=0.47, p<.001)$. These findings were partially unforeseen because with our first hypothesis we expected that couples in which only one parent worked nonstandard hours would provide the highest levels of parental child care. Table 2 further shows that schedule flexibility was not related to parental child care, whereas the association with home-based telework 
Table 1 Descriptives of childcare variables, work variables, and control variables $(\mathrm{N}=1599)$

\begin{tabular}{|c|c|c|c|}
\hline Variables & $M$ & $S D$ & Range \\
\hline Amount of provided parental child care (in days per week) & 2.62 & 1.24 & $0-5$ \\
\hline Formal child-care use $^{\mathrm{a}}$ & 0.62 & & $0-1$ \\
\hline Informal child-care use ${ }^{\mathrm{b}}$ & 0.67 & & $0-1$ \\
\hline \multicolumn{4}{|l|}{ Timing of work } \\
\hline Standard/standard & 0.45 & & $0-1$ \\
\hline Standard/nonstandard & 0.40 & & $0-1$ \\
\hline Nonstandard/nonstandard & 0.15 & & $0-1$ \\
\hline \multicolumn{4}{|l|}{ Schedule flexibility } \\
\hline None of the parents & 0.45 & & $0-1$ \\
\hline One of the parents & 0.32 & & $0-1$ \\
\hline Both of the parents & 0.23 & & $0-1$ \\
\hline \multicolumn{4}{|l|}{ Home-based telework } \\
\hline None of the parents & 0.60 & & $0-1$ \\
\hline One of the parents & 0.28 & & $0-1$ \\
\hline Both of the parents & 0.12 & & $0-1$ \\
\hline Couples' mean education $^{\mathrm{c}}$ & 0.39 & & $0-1$ \\
\hline Yearly household income (in $10,000 €$ ) & 8.94 & 4.34 & $0.41-44.86$ \\
\hline Age of target child & 3.08 & 2.02 & $0-6$ \\
\hline Number of children & 1.46 & 0.64 & $1-4$ \\
\hline Weekly overtime work ${ }^{\mathrm{d}}$ & 0.46 & & $0-1$ \\
\hline \multicolumn{4}{|l|}{ Actual weekly working hours } \\
\hline Mothers & 27.28 & 8.04 & $2-60$ \\
\hline Fathers & 38.16 & 4.79 & $10-60$ \\
\hline \multicolumn{4}{|l|}{$S D$ is not reported for dichotomous variables } \\
\hline \multicolumn{4}{|l|}{${ }^{\mathrm{a}}$ Formal child-care use: $0=n o, 1=$ yes } \\
\hline \multicolumn{4}{|l|}{${ }^{\mathrm{b}}$ Informal child-care use: $0=n o, 1=y e s$} \\
\hline \multicolumn{4}{|c|}{$\begin{array}{l}{ }^{\mathrm{c}} \text { Couples' mean education: } 0=\text { secondary education or lower, } 1=\text { postsecondary education or higher } \\
\mathrm{d} \text { Weekly overtime work: } 0=n o, 1=\text { yes, by at least one of the parents }\end{array}$} \\
\hline
\end{tabular}

The results of the multivariate logistic regression analysis concerning formal and informal child care are presented in the third and fourth column of Table 2. We would like to stress again that although the two types of care are analyzed simultaneously, formal and informal child care represent two separate binary variables that are not mutually exclusive.

Concerning the likelihood of using formal child care, Table 2 shows that couples in which one parent works nonstandard hours are significantly less likely to use formal child care than couples who only work standard hours $(O R=0.83, p=.014)$. This result indicates that so-called split-shift couples have a lower likelihood of using formal child care compared to standard working couples. More specifically, the predicted probability of split-shift couples using formal child care is $17 \%$ lower than that of standard working couples. This negative association was stronger for couples in which both parents work nonstandard hours $(O R=0.71, p=.001)$. The difference between couples in which one or both parents work nonstandard hours was not 
Table 2 Summary of OLS and logistic regression analyses for variables that predict the amount of provided parental child care, and couples' likelihood of using formal and informal child care $(\mathrm{N}=1599)$

\begin{tabular}{|c|c|c|c|c|c|c|c|c|c|}
\hline \multirow[t]{2}{*}{ Variable } & \multicolumn{3}{|c|}{ Parental child care } & \multicolumn{3}{|c|}{ Formal child care } & \multicolumn{3}{|c|}{ Informal child care } \\
\hline & $B$ & $S E B$ & $\beta$ & $B$ & $S E B$ & $O R$ & $B$ & $S E B$ & $O R$ \\
\hline \multicolumn{10}{|l|}{ Timing of work (ref. $=$ standard/standard $)$} \\
\hline Standard/nonstandard & 0.46 & 0.06 & $.18^{* * *}$ & -0.19 & 0.08 & $0.83^{*}$ & -0.16 & 0.08 & $0.85^{*}$ \\
\hline Nonstandard/nonstandard & 0.94 & 0.08 & $.27 * * *^{\mathrm{a}}$ & -0.34 & 0.10 & $0.71 * *$ & -0.24 & 0.10 & $0.79 *$ \\
\hline \multicolumn{10}{|l|}{ Schedule flexibility (ref. $=$ none) } \\
\hline One of the parents & -0.02 & 0.07 & -.01 & -0.00 & 0.08 & 1.00 & -0.04 & 0.08 & 0.96 \\
\hline Both of the parents & -0.01 & 0.08 & -.00 & 0.14 & 0.11 & 1.16 & -0.12 & 0.10 & 0.88 \\
\hline \multicolumn{10}{|l|}{ Home-based telework $($ ref. $=$ none $)$} \\
\hline One of the parents & 0.13 & 0.07 & $.05^{\dagger}$ & -0.11 & 0.09 & 0.90 & 0.06 & 0.09 & 1.06 \\
\hline Both of the parents & 0.18 & 0.10 & $.05^{\dagger}$ & -0.18 & 0.13 & 0.83 & -0.06 & 0.12 & 0.94 \\
\hline Couples' mean education ${ }^{\text {b }}$ & -0.26 & 0.07 & $-.10 * * *$ & 0.36 & 0.08 & $1.43 * * *$ & -0.20 & 0.08 & $0.82 *$ \\
\hline Yearly household income (in $10,000 €$ ) & -0.04 & 0.01 & $-.12 * * *$ & 0.05 & 0.01 & $1.05^{* * *}$ & -0.01 & 0.01 & 0.99 \\
\hline Age of target child & -0.02 & 0.02 & -.02 & -0.05 & 0.02 & $0.95^{*}$ & -0.15 & 0.02 & $0.86 * * *$ \\
\hline Number of children & 0.06 & 0.06 & .03 & -0.02 & 0.07 & 0.98 & 0.15 & 0.07 & $1.16^{\dagger}$ \\
\hline Weekly overtime work ${ }^{\mathrm{c}}$ & -0.19 & 0.06 & $-.08 * *$ & 0.08 & 0.08 & 1.08 & 0.07 & 0.07 & 1.07 \\
\hline \multicolumn{10}{|l|}{ Actual weekly working hours } \\
\hline Mothers & -0.05 & 0.00 & $-.32 * * *$ & 0.03 & 0.00 & $1.03 * * *$ & 0.00 & 0.00 & 1.00 \\
\hline Fathers & -0.03 & 0.01 & $-.12 * * *$ & 0.01 & 0.01 & 1.01 & 0.00 & 0.01 & 1.00 \\
\hline Constant & & $5.26 * * *$ & & & $-0.90 * *$ & & & $0.89 * *$ & \\
\hline$R^{2}$ & & .27 & & & & & & & \\
\hline$\chi^{2}(d f)$ & & & & & & & $259.82(26) * * *$ & & \\
\hline$\%$ used formal child care & & & & & 62.16 & & & & \\
\hline$\%$ used informal child care & & & & & & & & 67.35 & \\
\hline \multicolumn{10}{|c|}{${ }^{\dagger} p<.10 ; * p<.05 ; * * p<.01 ; * * * p<.001$} \\
\hline \multicolumn{10}{|c|}{${ }^{\mathrm{a}} p<.001$ (compared to standard/nonstandard) } \\
\hline \multicolumn{10}{|c|}{ b Couples' mean education: $0=$ secondary education or lower, $1=$ postsecondary education or higher } \\
\hline \multicolumn{10}{|c|}{${ }^{\mathrm{c}}$ Weekly overtime work: $0=n o, 1=y e s$, by at least one of the parents } \\
\hline Source: KiK'13 & & & & & & & & & \\
\hline
\end{tabular}

significant. These results are partially consistent with Hypothesis 3. No significant effects were found for schedule flexibility or home-based telework for predicting couples' likelihood of using formal child care, indicating that we found no results that were consistent with Hypotheses $4 \mathrm{a}$ or $4 \mathrm{~b}$. The effects of the control variables show that couples' likelihood of using formal child care is higher if they have attained a higher level of education $(O R=1.43, p=<.001)$, if they have a higher yearly household income $(O R=1.05, p=<.001)$, and if the mother works more hours $(O R=1.03, p=<.001)$. On the other hand, having an older target child decreased the likelihood of using formal child care $(O R=0.95$, $p=.042$ ).

Finally, the fourth column of Table 2 presents the results concerning the likelihood of using informal child care. The results indicate that couples in which one $(O R=0.85, p=.042)$ or both parents $(O R=0.79$, $p=.021)$ work nonstandard hours are significantly less likely to use informal child care than couples with two standard working parents. This negative association was somewhat stronger for couples in which both parents work nonstandard hours. More specifically, the predicted probability of using informal child care is respectively 15 and $21 \%$ lower for split-shift couples and nonstandard working couples compared to standard working couples. There was no significant difference between couples in which one or both parents work nonstandard hours. These findings are in contrast with Hypothesis 5 because we expected couples in which both parents work standard hours to have the lowest likelihood of using informal child care. Neither schedule flexibility nor home-based telework was significantly associated with the likelihood of using informal child care. The results of the control variables indicate that the likelihood of using informal child care is lower if couples have attained a higher level of education $(O R=0.82$, 
$p=.016)$, and if the target child is older $(O R=0.86$, $p<.001)$. Alternatively, having more children increased couples' likelihood of using informal child care $(O R=0.15, p=.050)$.

In addition to the gender-neutral analyses, we performed additional analyses (not shown; available upon request) to examine possible gender differences in the effects of parental work schedules. First, concerning the amount of provided parental child care, we found that couples in which only the mother works nonstandard hours provide significantly more parental child care than couples in which only the father works nonstandard hours $(B=0.22$, $p=.014)$, which is consistent with our gender-specific expectations concerning parental child care. Regarding schedule flexibility and home-based telework, we found no significant gender differences in the amount of provided parental child care. This finding is in contrast with our gender-specific expectations because we expected mothers' additional working conditions to have a stronger association with parental child care than those of fathers. Second, regarding the likelihood of using formal child care, we found no gender differences. Third, the likelihood of using informal child care was lower for couples in which only the mother had schedule flexibility than for couples in which this was only the case for fathers $(O R=0.80, p=.077)$. No further gender differences were found.

\section{Discussion}

In this study, we examined the associations between couples' work schedules and child-care arrangements among 1599 dual-earner couples in the Netherlands. We improved upon prior research by considering both parental and nonparental child care and by examining multiple dimensions of parental work schedules. We also tested whether the associations between parental work and child-care arrangements differed between mothers and fathers.

Previous research on the timing of parental work and child care has mainly focused on the care that parents themselves provide (Carriero et al. 2009; Täht and Mills 2012). We extended this line of research by considering nonparental care. For this type of care, the timing of parental work plays a central role as well; we found that working nonstandard hours decreased the likelihood of using both formal and informal child care. Because the use of both types of nonparental child care decreased, nonstandard working couples seem to not be less likely to use formal child care due to a lack of availability (Kim and Fram 2009). If this were true, the results would have shown an increase in the likelihood of using informal child care. Contrary to previous studies (Han 2004; Presser 2003), which found that nonstandard working couples relied heavily on informal child care, we found that nonstandard work made couples less likely to use care provided by relatives or friends. This divergent finding may be due to our sample, which included many families with only one child, whereas Thomese and Liefbroer (2013) showed that the involvement of Dutch grandparents is higher if parents have more than one child. The specific context of the Dutch labor market, with the high prevalence of part-time work (EU Labour Force Survey 2013), may also have resulted in different findings compared with previous studies. Even though we controlled for weekly working hours, the work schedules of Dutch parents are likely to be less restrictive due to the shorter working time. Hence, the parents in our sample might have a lower need of nonparental child care.

We also replicated previous research in our examination of the associations between parental work and parental child care, defined here as care that is provided by one parent while the other parent is at work. Our results show that nonstandard working hours increased the amount of provided parental child care. Parental child care was highest among couples in which both parents worked nonstandard hours, which is in contrast to Presser's (2003) notion about split-shift couples. In the Netherlands, however, different labor legislation and regulations exist (Täht and Mills 2012), which may make Dutch nonstandard work more suitable for dividing care between two nonstandard working parents. Indeed, previous research has indicated that Dutch parents tend to de-synchronize their working hours, whereas parents from other countries tend to do the opposite (Carriero et al. 2009).

To obtain more insight into couples' child-care opportunities and constraints, we looked beyond the timing of the work and examined schedule flexibility and homebased telework. Our results show that home-based telework increased the amount of care parents provide themselves. This is in line with our expectations; working from home enables parents to better combine work and family demands because this type of work makes it possible to structure the day around children's schedules and provide more child care (Osnowitz 2005). This finding implies that it is not sufficient to focus on one dimension of parental work; work schedules should be examined using a broad perspective. In addition, a gender-neutral approach is not justified because our results show that couples in which only the mother worked nonstandard hours provided more parental child care than couples in which only the father worked nonstandard hours. Additionally, couples in which only the mother has schedule flexibility were less likely to use informal child care than were coupes in which only the father has schedule flexibility.

Our findings are partially consistent with our theoretical framework. We applied an opportunities and constrains framework that incorporated multiple dimensions of 
parental work that were likely to affect parents' opportunities and constraints when arranging different types of child care. Although not all of the dimensions of parental work were linked to child care, our approach indicates that if we want to understand parents' child-care arrangements we have to consider when parents work and how they organize their working day. Our results namely indicate that not only nonstandard working hours, but also homebased telework increases parents' opportunities to provide parental child care.

Although this study provided more insight into the childcare arrangements of Dutch dual earners, there is still considerable room for improvement. First, the data were selfreported and cross-sectional, which makes it difficult to rule out selection effects. Parents may choose to work a certain schedule because they want to minimize their use of nonparental child care. Ideally, we would like to study how parents' work schedules change over the life course to ensure that we capture how their work is related to their child-care decisions. Second, our measure of nonstandard work was less detailed than in previous studies. For example, parents who work standard hours with one additional evening every week could, in our study, have been classified as working nonstandard hours, which may have blurred our results. Additionally, our measure of nonstandard work was not able to capture the actual overlap in couples' work schedules, although overlap is an important mechanism. Therefore, a more accurate measure that differentiates between nonstandard hours and days (Presser 2003) and measures actual overlap (Lesnard 2008) is desirable. Third, although this paper focuses on dual-earner couples, the data were only collected from one of the parents within these couples. Although we expect respondents to be quite accurate about their partner's timing of work or working hours, they may be less aware of the schedule flexibility of their partner. A multi-actor approach could provide more insight into possible differences between partners.

In our attempt to deepen the understanding of how parents arrange the care for their children we focused on parental work schedules. We hereby assumed that the level of overlap would be highest for two standard working parents, lower for two nonstandard working parents and lowest for split-shift couples. However, we are not aware of any empirical tests of this assumption. Lesnard (2008) takes an important step in this direction, but does not seem to include families in which both partners work during nonstandard hours. So far, a surprisingly limited number of studies examined this group of parents. Future research could therefore focus on measuring the level of overlap in the working hours of nonstandard working couples and compare this with other schedule combinations. Yet, other micro and macro factors may also affect parents' opportunities and constraints. Previous research has indicated that the supply of formal child care is strongly related to parents' child-care choices (Liu 2013). Aspects like the proximity or the opening hours of child-care institutions, or the quality of the caregivers, are therefore important factors to consider. Future research could take the supply of child care into account and study whether parents with nonstandard schedules respond differently to this. Furthermore, parental norms may also relevant, especially in the Netherlands where parents believe children should not spend too much time in formal child care (Merens et al. 2012). Future research on the link between parental work and child care should explore how parental norms affect this decision-making process. Another interesting venue for future research would be to focus on work-family policies. For example, policies on parental leave have been found to affect both parental work and the use of nonparental child care (Saraceno 2011). Scholars may therefore want examine how work-family policies affect parents' opportunities and constraints when arranging child care. Lastly, future research could try to disentangle the relationship between child-care arrangements and parental well-being. Couples who provide a significant amount of parental child care may, for instance, reduce their hours of sleep or their couple time (Wight et al. 2008), which could negatively affect parental well-being. Thus, the decisions that parents make regarding their child's benefit may be harmful to themselves.

In conclusion, our study showed that parental nonstandard work enhances parental child care, whereas work during evenings, nights, and weekends decreases couples' likelihood of using nonparental child care. Moreover, we showed that home-based telework increases parental child care. By taking a couple-level approach and distinguishing between mothers and fathers we showed that gender moderated the effects of work schedules on child-care use. If we consider our results from the perspective of child well-being, which is enhanced by parental care (e.g., Hsin 2008; Wurtz 2008), our results suggest that policy makers could capitalize on the positive effects of nonstandard work and home-based telework on parental care. Currently, Dutch interest groups defending the rights of workers mostly focus on the negative consequences of work during evenings, nights, and weekends (e.g., "Alles over onregelmatig werk" 2015). Our study, in contrast, suggests that it could be an instrument to maximize parental care and could therefore also be considered as a possible resource. By also considering possible positive consequences for family life, policy makers can introduce a more balanced view towards nonstandard work. Dutch policies regarding home-based telework have recently been adapted, now enabling employees to request the right to work from home ("Thuiswerken wordt wettelijk recht" 2015). However, since employers are still able to deny this request, policy makers need to continue 
to make sure that home-based telework is actually used. For example, the national and local government could lead by example or inform employees and employers about the benefits. If these two work conditions are enhanced, policy makers may be able to help parents balance the coordination of everyday life and reduce feelings of conflict and time pressure.

Acknowledgments The authors wish to thank the Netherlands Institute for Social Research and the Dutch Bureau of Statistics, and in particular Wil Portegijs, Mariëlle Cloïn and Ans Merens, for enabling us to include additional questions in the survey and for providing us with the data.

Funding This study was funded by the Netherlands Organization for Scientific Research (Research Talent Grant 406-13-051).

\section{Compliance with Ethical Standards}

Ethical Approval For this type of study formal consent is not required.

\section{References}

Alles over onregelmatig werk [Everything on irregular work]. (2015). Menzis intermediar. Retrieved from http://www.menzis.nl.

Anderson, S. E., Coffey, B. S., \& Byerly, R. T. (2002). Formal organizational initiatives and informal workplace practices: Links to work-family conflict and job-related outcomes. Journal of Management, 28, 787-810.

Bakker, W., \& Karsten, L. (2013). Balancing paid work, care and leisure in post-separation households: A comparison of single parents with co-parents. Acta Sociologica, 56, 173-187.

Barnes, M., Bryson, C., \& Smith, R. (2006). Working atypical hours: What happens to family life. London: National Centre for Social Research.

Bielby, D. D. (1992). Commitment to work and family. Annual Review of Sociology, 18, 281-302.

Bradley, R. H., \& Vandell, D. L. (2007). Child care and the wellbeing of children. Archives of Pediatrics and Adolescent Medicine, 161, 669-676.

Brown-Lyons, M., Robertson, A., \& Layzer, J. (2001). Kith and kinInformal child care: Highlights from recent research. New York: National Center for Children in Poverty.

Byron, K. (2005). A meta-analytic review of work-Family conflict and its antecedents. Journal of Vocational Behavior, 67, 169-198.

Carriero, R., Ghysels, J., \& Van Klaveren, C. (2009). Do parents coordinate their work schedules? A comparison of Dutch, Flemish, and Italian dual-earner households. European Sociological Review, 25, 603-617.

Casper, L. M., \& Smith, K. E. (2004). Why do parents leave their children unsupervised? Demography, 41, 285-301.

Chaudry, A. (2004). Putting children first: How low-wage working mothers manage child care. New York: Russell Sage Foundation.

Cloïn, M., Schols, M., Van den Broek, A., \& Koutamanis, M. (2010). Tijd op orde? Een analyse van de tijdsorde vanuit het perspectief van de burger [Time on budget? An analysis of time management from the perspective of the citizen]. The Hague: Netherlands Institute for Social Research.

Craig, L., \& Powell, A. (2011). Non-standard work schedules, workfamily balance and the gendered division of childcare. Work, Employment \& Society, 25, 274-291.
De Leeuw, E. D., \& De Heer, W. (2001). Trends in household survey nonresponse: A longitudinal and international comparison. In R. M. Groves, D. A. Dillman, J. L. Eltinge, \& R. J. A. Little (Eds.), Survey nonresponse (pp. 41-54). New York: Wiley.

Duncan, S., Edwards, R., Reynolds, T., \& Alldred, P. (2004). Mothers and child care: Policies, values and theories. Children and Society, 18, 254-265.

Duncan, K. A., \& Pettigrew, R. N. (2012). The effect of work arrangements on perception of work-family balance. Community, Work \& Family, 15, 403-423.

Dutch Bureau of Statistics. (2012a). Beroepsbevolking; behaalde onderwijs naar herkomst geslacht en leeftijd [Labor force participation; attained level of education by origin, gender and age]. Retrieved from http://statline.cbs.nl.

Dutch Bureau of Statistics. (2012b). Gemiddeld inkomen; particuliere huishoudens naar diverse kenmerken [Mean income; private households by multiple characteristics]. Retrieved from http://statline.cbs.nl.

Dutch Bureau of Statistics. (2014). Minder kinderen naar kinderdagverblijven [Less children to day-care]. Retrieved from http://www.cbs.nl/nl-NL/menu/themas/dossiers/jongeren/publica ties/artikelen/archief/2014/2014-4024-wm.htm.

Dutch Government. (2014). Welke vormen van kinderopvang zijn er? [Which types of child care exist?]. Retrieved from http://www. rijksoverheid.nl/onderwerpen/kinderopvang/vraag-en-antwoord/ welke-vormen-van-kinderopvang-zijn-er.html.

Dutch Ministry of Social Affairs and Employment. (2014). Kamerbrief cijfers kinderopvang 2013. [Letter to the House of Representatives concerning the 2013 child-care figures]. Retrieved from http://www.rijksoverheid.nl/documenten-en-publicaties/kamer stukken/2014/03/24/kamerbrief-cijfers-kinderopvang-2013.html.

Dykstra, P. A., Kalmijn, M., Knijn, T. C. M., Liefbroer, A. C., \& Mulder, C. H. (2005). Codebook of the Netherlands Kinship Panel Study: A multi-actor, multi-method panel study on solidarity in family relationships, wave 1 (NKPS Working Paper No 5). The Hague: Interdisciplinary Demographic Institute.

EACEA. (2009). Early childhood education and care in Europe: Tackling social and cultural inequalities: The Netherlands. Brussels: EACEA.

Early, D., \& Burchinal, M. (2001). Early childhood care: Relations with family characteristics and preferred care characteristics. Early Childhood Research Quarterly, 16, 475-497.

Ehrle, J., Adams, G., \& Tout, K. (2001). Who's caring for our youngest children?: Child care patterns of infants and toddlers. Washington, DC: Urban Institute.

EU Labour Force Survey. (2013). Part-time employment as a percentage of the total employment, by sex and age (\%). Retrieved from http://epp.eurostat.ec.europa.eu/portal/page/por tal/statistics/search_database.

Fleetwood, S. (2007). Why work-life balance now? International Journal of Human Resource Management, 18, 387-400.

Gareis, K. C., Barnett, R. C., \& Brennan, R. T. (2003). Individual and crossover effects of work schedule fit: A within-couple analysis. Journal of Marriage and Family, 65, 1041-1054.

Han, W. J. (2004). Nonstandard work schedules and child care decisions: Evidence from the NICHD Study of Early Child Care. Early Childhood Research Quarterly, 19, 231-256.

Hattery, A. J. (2001). Tag-team parenting: Costs and benefits of utilizing nonoverlapping shift work in families with young children. Families in Society: The Journal of Contemporary Human Services, 82, 419-427.

Hsin, A. (2008). Parenting, investments in children and the social reproduction of skills and status. (Doctoral dissertation). University of California, Los Angeles.

Kim, J., \& Fram, M. S. (2009). Profiles of choice: Parents' patterns of priority in child care decision-making. Early Childhood Research Quarterly, 24, 77-91. 
Kimmel, J., \& Powell, L. M. (2006). Nonstandard work and child care choices of married mothers. Eastern Economic Journal, 32, 397-419.

Leslie, L. A., Ettenson, R., \& Cumsille, P. (2000). Selecting a child care center: What really matters to parents? Child \& Youth Care Forum, 29, 299-322.

Lesnard, L. (2008). Off-scheduling within dual-earner couples: An unequal and negative externality for family time. American Journal of Sociology, 114, 447-490.

Liu, M. (2013). An ecological review of literature on factors influencing working mothers' child care arrangements. Journal of Child and Family Studies, 22, 1-11.

Lu, M., \& Yang, W. (2012). Multivariate logistic regression analysis of complex survey data with application to BRFSS data. Journal of Data Science, 10, 157-173.

Merens, A., Hartgers, M., \& Van den Brakel, M. (2012). Emancipatiemonitor 2012 [Emancipation monitor 2012]. The Hague: Netherlands Institute for Social Research.

Mills, M., Mencarini, L., Tanturri, M. L., \& Begall, K. (2008). Gender equity and fertility intentions in Italy and the Netherlands. Demographic Research, 18, 1-26.

Moilanen, S., May, V., Räikkönen, E., Sevón, E., \& Laakso, M.-L. (in press). Mothers' non-standard working and childcare-related challenges: A comparison between lone and coupled mothers. International Journal of Sociology and Social Policy.

Netherlands Institute for Social Research \& Dutch Bureau of Statistics. (2013). Krimp in Kinderopvang [Contraction in childcare]. The Hague: Netherlands Institute for Social Research.

OECD Family Database. (2009). Maternal employment. Retrieved from http://www.oecd.org/els/family/oecdfamilydatabase.htm.

OECD Family Database. (2012). Children in families by employment status. Retrieved from http://www.oecd.org/els/social/family/ database.

Osnowitz, D. (2005). Managing time in domestic space home-based contractors and household work. Gender \& Society, 19, 83-103.

Peters, P., \& Den Dulk, L. (2003). Cross cultural differences in managers' support for home-based telework: A theoretical elaboration. International Journal of Cross Cultural Management, 3, 329-346.

Plantenga, J., \& Remery, C. (2009). The provision of childcare services. A comparative review of 30 European countries. Brussels: European Commission DG for Employment, Social Affairs and Equal Opportunities.

Portegijs, W., Cloïn, M., \& Merens, A. (2014). Contraction in childcare. The Hague: Netherlands Institute for Social Research.

Presser, H. B. (2003). Working in a 24/7 economy: Challenges for American families. New York: Russell Sage Foundation.
Presser, H. B., Gornick, J. C., \& Parashar, S. (2008). Gender and nonstandard work hours in 12 European countries. Monthly Labor Review, 131, 83-103.

Roeters, A., Van der Lippe, T., \& Kluwer, E. S. (2009). Parental work demands and the frequency of child-related routine and interactive activities. Journal of Marriage and Family, 71, 1193-1204.

Roeters, A., Van Der Lippe, T., \& Kluwer, E. S. (2010). Work characteristics and parent-child relationship quality: The mediating role of temporal involvement. Journal of Marriage and Family, 72, 1317-1328.

Sandstrom, H., \& Chaudry, A. (2012). 'You have to choose your childcare to fit your work': Childcare decision-making among low-income working families. Journal of Children and Poverty, $18,89-119$.

Saraceno, C. (2011). Childcare needs and childcare policies: A multidimensional issue. Current Sociology, 59, 78-96.

Täht, K., \& Mills, M. C. (2012). Nonstandard work schedules, couple desynchronization and parent-child interaction: A mixed-method analysis. Journal of Family Issues, 33, 1054-1087.

Thomese, F., \& Liefbroer, A. C. (2013). Child care and child births: The role of grandparents in the Netherlands. Journal of Marriage and Family, 75, 403-421.

Thuiswerken wordt wettelijk recht [Home-based telework becomes legal right]. (2015). De Volkskrant. Retrieved from http://www. volkskrant.nl/.

Tijdens, K., \& Dragstra, A. (2007). 'How many hours do you usually work?': An analysis of the working hours questions in 26 largescale surveys in six countries and the European Union. Time \& Society, 16, 119-130.

Van Klaveren, C., Maassen van den Brink, H., \& Van Praag, B. (2013). Intra-household work timing: The effect on joint activities and the demand for child care. European Sociological Review, 29, 1-18.

Van Wel, F., \& Knijn, T. (2006). Transitional phase or a new balance? Working and caring by mothers with young children in the Netherlands. Journal of Family Issues, 27, 633-651.

Wheelock, J., \& Jones, K. (2002). Grandparents are the next best thing: Informal childcare for working parents in urban Britain. Journal of Social Policy, 31, 441-463.

Wight, V. R., Raley, S. B., \& Bianchi, S. M. (2008). Time for children, one's spouse and oneself among parents who work nonstandard hours. Social Forces, 87, 243-271.

Wurtz, A. (2008). Child outcomes: Parental time investments and school characteristics. (Doctoral dissertation). Århus University, Denmark.

Zinsser, C. (2001). Child care within the family. The Future of Children, 11, 123-127. 